\title{
Most corals may not change their symbionts
}

\author{
Tamar L. Goulet* \\ 524 Shoemaker Hall, Department of Biology, University of Mississippi, University, Mississippi 38677, USA
}

\begin{abstract}
Many corals (stony corals and octocorals) rely on their symbiotic algae (zooxanthellae) for survival. Under stress, zooxanthellae are expelled, resulting in coral bleaching. The hypothesis that corals may survive climate change by exchanging algal types is shown here to be potentially applicable only to a minority of corals. Data on 442 coral species from 43 studies reveal that only a few coral species may be able to change their symbionts. The ability to change symbionts seems to be linked to whether a coral species can host multiple zooxanthella clades, either at different depths on the same reef, on different reefs or at different geographic locations, or concurrently within the same colony. The combined data set shows that only $23 \%$ of coral species host multiple zooxanthella clades. Most coral species (77\%) exhibit fidelity to a narrow subset of a single zooxanthella clade, some even to specific algal genotypes within a clade. These specific algal genotypes in coral species hosting a single algal clade do not change over time. Furthermore, no algal change occurs when a coral colony is either transplanted to different environments, or subjected to stressors such as disease or increased temperatures. For the majority of corals, therefore, algal switching does not appear to occur. These coral species will survive only if the existing host-symbiont combination withstands the changing conditions. If climate warming continues, coral reefs may undergo a change in biodiversity such that only a subset of symbiotic corals may persist.
\end{abstract}

KEY WORDS: Zooxanthella · Coral · Bleaching · Global warming · Clade · Symbiosis · Adaptive bleaching hypothesis

Resale or republication not permitted without written consent of the publisher

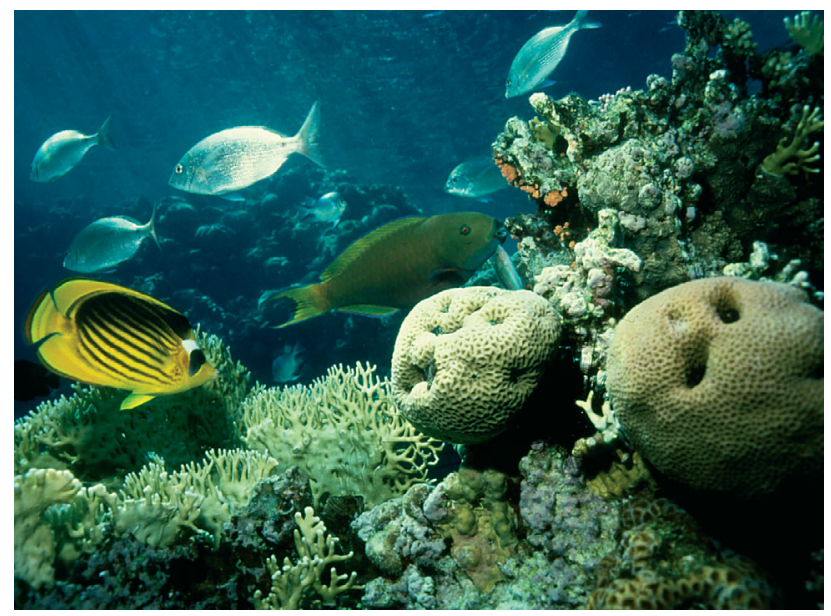

Most corals host only one zooxanthella clade and do not change their algae, neither over time, nor after exposure to elevated temperatures, disease, or following transplantation.

Photo: Denis Goulet

\section{INTRODUCTION}

Many stony corals and octocorals (collectively referred to hereafter as corals) form an obligatory mutualism with unicellular algae (zooxanthellae). Under stressful environmental conditions, such as elevated water temperatures, there is a loss of zooxanthellae and/or their photosynthetic pigments, a phenomenon commonly called coral bleaching (Glynn 1996). According to the adaptive bleaching hypothesis, bleaching may enable corals to adopt zooxanthellae better suited for a new environment (Buddemeier \& Fautin 1993). These algae may enter the symbiosis from exogenous sources (symbiont 'switching') or, if multiple zooxanthellae already concurrently exist within the host, a shift in symbiont dominance may occur (symbiont 'shuffling') (Baker 2003). 
The possibility of zooxanthella turnover is particularly appealing in light of global warming and the predictions that coral symbioses, as we know them, are reaching their thermal limits (Hoegh-Guldberg 1999). Numerous recent studies on zooxanthella genotypes in corals have focused on zooxanthella turnover (Rowan et al. 1997, Baker 2001, Baker et al. 2004, Lewis \& Coffroth 2004, Little et al. 2004, Rowan 2004, Berkelmans \& van Oppen 2006). It has been suggested that corals may survive global climate change by switching their symbiotic algae (Buddemeier \& Fautin 1993, Little et al. 2004, Rowan 2004). Fautin \& Buddemeier (2004) even stated that adaptive bleaching is a general phenomenon. The possibility of algal switching or shuffling, however, relies on the assumption that a coral species can host multiple algal genotypes, either sequentially or simultaneously.

The distinction between zooxanthella genotypes is based on different parts of the zooxanthella genome such as nuclear genes encoding either the small subunit (SSU) or the large subunit (LSU) of the ribosomal RNA, internal transcribed spacers (ITS1 and ITS2), 5.8S regions and large subunit chloroplast rDNA (cprDNA). The various genome regions have yielded a relatively robust division of zooxanthellae into 8 clades $(\mathrm{A}-\mathrm{H})$. These clades are found in a variety of host phyla such as Cnidaria (e.g. corals, octocorals, sea anemones), Mollusca (e.g. clams), Porifera (e.g. sponges), and Protozoa (e.g. foraminiferans) (Stat et al. 2006, their Table 1). Each clade includes multiple zooxanthella 'types' (see reviews by Baker 2003, Coffroth \& Santos 2005, Stat et al. 2006).

In the 15 yr since the cladal division of zooxanthellae was first introduced, numerous researchers have reported the cladal identity of zooxanthellae in 442 coral species from multiple geographic locations. The objective of this study was to use this large dataset to reach conclusions about coral-algal symbioses and the possibility and generality of symbiont turnover in times of global climate change.

\section{METHODS}

Since 1991, 43 studies included data on the zooxanthella genetic identity in 442 scleractinian corals and octocoral species (Table 1). In this study these data were pooled into 1 large data set, using only data published from field-collected samples, and not from zooxanthella cultures, since culturing is highly selective (Goulet \& Coffroth 1997, Santos et al. 2001, LaJeunesse 2002). Most reports identified zooxanthellae at the cladal level, with a few reporting resolution within-clades. Comparison of zooxanthella types is hampered by the fact that researchers use different

parts of the genome for the within-clade division and there is no generally accepted nomenclature of the zooxanthella types. Data analysis was therefore conducted at the cladal level with further comparisons at the within-clade level as the data permitted.

A coral species was defined as hosting multiple zooxanthella clades if that coral species hosted $>1$ zooxanthella clade at different depths, in different geographic locations, at different sampling times, or within the same colony. A coral species was classified as hosting multiple zooxanthella clades with no distinction being made as to whether the multiple clades were a result of algal 'switching' or algal 'shuffling' (internal turnover as described in Baker 2003).

To determine if a geographic pattern existed, data was entered in tabular format in order to create a GIS (Geographic Information System) map using ArcMap (v8.3, ESRI). The GIS includes a world map as the primary base layer. A geographic coordinate system was used for the spatial component of the samples. The latitude and longitude coordinates of the samples were converted to decimal format. The data were plotted to reveal any spatial patterns in the distribution of coral species hosting single versus multiple zooxanthella clades.

\section{RESULTS AND DISCUSSION}

In a changing environment, such as that encountered in times of global climate change, not all coral species fare the same (Loya et al. 2001, Douglas 2003). Differential survival of corals can be attributed to a coral colony's tolerance (Brown et al. 2002, Bhagooli \& Hidaka 2004), the zooxanthellae's tolerance (Rowan et al. 1997), or both.

Table 1. Data sources for the meta-analysis on coral symbionts

Baker $(1999,2001)$

Baker \& Rowan (1997)

Baker et al. $(1997,2004)$

Barneah et al. (2004)

Billinghurst et al. (1997)

Chen et al. (2005)

Darius et al. $(1998,2000)$

Diekmann et al. $(2002,2003)$

Fabricius et al. (2004)

Goulet \& Coffroth (2004)

Goulet et al. (unpubl.)

Iglesias-Prieto et al. (2004)

Karako-Lampert et al. (2004)

LaJeunesse (2002)

LaJeunesse et al. $(2003,2004,2005)$

Loh et al. $(1997,2001)$
McNally et al. (1994)

Rodriguez-Lanetty \&

Hoegh-Guldberg (2003)

Rodriguez-Lanetty et al.

(2000, 2003, 2004)

Rowan \& Knowlton (1995)

Rowan \& Powers (1991a,b)

Rowan et al. (1997)

Santos et al. $(2001,2003 a, b)$

Savage et al. (2002)

Toller et al. (2001b)

Ulstrup \& van Oppen (2003)

van Oppen et al. (2001)

Visram \& Douglas (2006)

Wilcox $(1997,1998)$

Yang et al. (2002) 


\section{Association between corals and zooxanthella genotypes}

Recombination of coral-zooxanthella genotypic combinations may be advantageous (Buddemeier \& Fautin 1993) and a way for the slowly evolving corals to adapt or acclimate to the rapidly changing conditions (Baker et al. 2004). Different coral-zooxanthella genotypic combinations may display different physiologies. For example, in Pocillopora spp. $32^{\circ} \mathrm{C}$ causes photoinhibition in Clade $\mathrm{C}$ containing colonies, while causing photoprotection in colonies hosting Clade D zooxanthellae (Rowan 2004). Similarly, Acropora millepora hosting Clade D zooxanthellae exhibit a higher thermal tolerance compared to colonies hosting Clade C zooxanthellae (Berkelmans \& van Oppen 2006). Physiologies dependent on the host-symbiont combination are also seen in the sea anemone Aiptasia pallida, in which 2 natural and 1 artificial host-symbiont combinations (with Clade A and B zooxanthellae) yielded 3 different physiological responses to elevated temperatures (Goulet et al. 2005). In all of these examples, the host naturally associates with zooxanthellae from several clades.

A key assumption of algal symbiont change is that corals can host multiple zooxanthella genotypes, either concurrently or sequentially. Combining data published from 1991 to 2006 generated a data set of zooxanthella identity from 442 coral species (both scleractinian corals and octocorals, Table 1). Sample sizes for number of colonies sampled from a particular coral species ranged from 1 to 565 with only $18 \%$ represented by a sample size of 1 . Many genera were represented by multiple species. In many instances, the same species was sampled from multiple reefs and multiple geographic locations, during multiple years, at different times throughout the year, and by different researchers. The current data demonstrate that, as adults, most coral species may not be able to change their zooxanthella population. Coral-algal recombination, therefore, may not be a viable option for most coral species. Four lines of evidence support this conclusion.

(1) Most corals host a single zooxanthella clade. Analyzing coral-zooxanthella symbioses at the cladal level reveals that coral species fall into 2 categories. The first category contains coral species that can host multiple zooxanthella clades either over depth on the same reef, in different geographic areas, or within the same colony. Coral species in this category are in the minority, since only $23 \%$ of the coral species sampled hosted multiple zooxanthella clades (Fig. 1). The second category includes the majority of coral species $(77 \%)$. These coral species host only 1 zooxanthella clade. A global comparison demonstrated that hosting

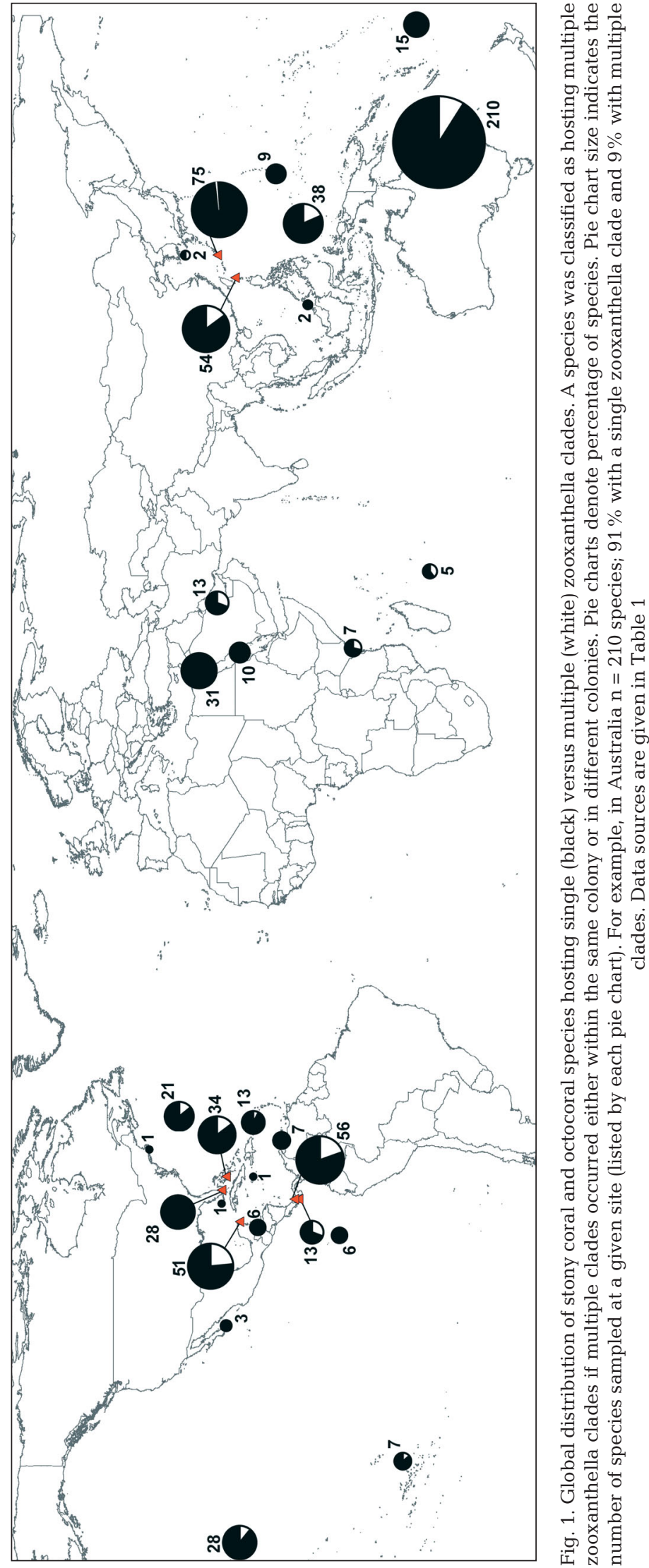


a single zooxanthella clade is prevalent worldwide (Fig. 1). Although the fact that most coral species host 1 zooxanthella clade has been noted previously (LaJeunesse 2002, Baker 2003), the implications of the existence of multiple versus single zooxanthella clades within a coral species have not been discussed.

All documented instances of long-term change in symbiont populations, for example, have been reported from corals that naturally host multiple zooxanthella clades (Baker 2001, Baker et al. 2004, Berkelmans \& van Oppen 2006). In a 12 mo transplant experiment, 7 out of the 8 scleractinian coral species sampled displayed a change in their zooxanthella clade (Baker 2001). These species, however, naturally host zooxanthellae of different clades. Coral colonies in the genus Pocillopora host both Clade C and D zooxanthellae, and following a bleaching event, most colonies hosted Clade D (Baker et al. 2004). Acropora millepora colonies transplanted for 9 mo shifted between the 2 zooxanthella clades found in this species, Clades C and D, while other colonies of $A$. millepora from another site did not change their Clade $\mathrm{C}$ zooxanthellae during a 14 mo transplant (Berkelmans \& van Oppen 2006). Corals hosting multiple clades may demonstrate a shift or switch in algal clades, but they may be the exception rather than the norm.

(2) Coral species that host a single zooxanthella clade do not demonstrate algal turnover even at the within-clade level. Long-term studies (>6 mo) of coral species hosting a single algal clade reveal that zooxanthella genotypic fidelity even exists at the within-clade level (Goulet \& Coffroth 2003a,b, Rodriguez-Lanetty et al. 2003, Iglesias-Prieto et al. 2004, LaJeunesse et al. 2004, 2005, Kirk et al. 2005), and down to the level of individual zooxanthella genotype (Goulet \& Coffroth $2003 \mathrm{~b})$. This is found when comparing coral colonies within a species over time, after transplantation to novel environments, exposure of coral colonies to disease, or elevated temperatures (Table 2).

Rodriguez-Lanetty et al. (2003) sampled zooxanthellae in the scleractinian coral Alveopora japonica in different seasons throughout the year. Using sequences of LSU and ITS1 rDNA, they determined that $A$. japonica in all instances hosted zooxanthellae belonging to Clade F. Using DNA fingerprinting to distinguish among zooxanthella genotypes, Goulet \& Coffroth (2003b) followed colonies of the octocoral Plexaura kuna over a 10 yr period that included a bleaching event. The $P$. kuna colonies retained the original individual zooxanthella genotype in all samples collected over this $10 \mathrm{yr}$ period (Goulet \& Coffroth 2003b). In addition, all $P$. kuna clonemates, a reflection of the octocoral genotype over time, exhibited the same individual zooxanthella genotype (Goulet \& Coffroth 2003b).

Transplantation of colonies of coral species that host a single algal clade also did not induce an algal turnover, neither at the cladal nor sub-cladal level. The same zooxanthella genotype persisted after transplanting Plexaura kuna colonies to novel environments for 20 mo (Goulet \& Coffroth 2003b). Pavona gigantea kept its specific sub-clade of zooxanthellae (Clade C1c) a year after transplantation to a shallow depth (Iglesias-Prieto et al. 2004). A Porites compressa colony collected below $10 \mathrm{~m}$ and transplanted to a shallow patch reef maintained its deep-water zooxanthella type (C15b) even $10 \mathrm{yr}$ after being transplanted (LaJeunesse et al. 2004). Fungia scutaria retained its original zooxanthella type (C1b) for $35 \mathrm{yr}$ after being transplanted from the Indo-Pacific to the Caribbean, (LaJeunesse et al. 2005). This finding is of particular interest since Clade $\mathrm{C} 1 \mathrm{~b}$ is not found in the Caribbean.

A comparison of a hypervariable region within the large subunit of the choloroplast ribosomal gene in zooxanthellae in healthy and diseased Gorgonia ventalina revealed that all $G$. ventalina, regardless of their health, hosted a single Clade B sub-clade (Kirk et al. 2005). Furthermore, in laboratory experiments, where $G$. ventalina colonies were subjected to elevated temperature for varying times, G. ventalina did not switch its zooxanthella sub-clade (Kirk et al. 2005).

In summary, all studies on coral species that host a single zooxanthella clade show no algal turnover at the clade or sub-clade level.

(3) No study has demonstrated that coral species hosting a single zooxanthella clade form new symbiotic combinations with 'cryptic zooxanthellae'. It has been suggested that the algal genotypes identified from specific coral hosts are actually an underestimation of the genotypes that exist within the host species 
(Baker 2003). Proponents for these undetected (cryptic) multiple genotypes base their suggestion on results obtained with either: (1) zooxanthella cultures, or (2) from working with particular molecular techniques. Considering (1), in some instances zooxanthella clades are cultured from a coral that are not known to associate with that coral in nature (Goulet \& Coffroth 1997, Santos et al. 2001, LaJeunesse 2002). (2) Using a cloning approach, for instance, algal genotypes have been described that have not surfaced from surveying zooxanthellae extracted from corals in the wild. Some of the presumed variability in zooxanthella genotypes, however, may be an artifact of the molecular technique used. For example, cloning may generate sequences that do not represent zooxanthellae (Toller et al. 2001a, Baker 2003).

The role and importance of 'cryptic zooxanthellae', if they exist and are not an artifact of a technique, has not been demonstrated. There is no evidence that the additional algal genotypes obtained via culturing or a molecular technique are in symbiosis with the host; they might be 'transient' or 'opportunistic contaminant' algal cells found externally or internally, but without constituting part of the symbiosis (Santos et al. 2001, LaJeunesse 2002, LaJeunesse et al. 2004). Furthermore, if a coral species is known to host multiple clades, then background levels of the multiple clades may occur. In coral species that host a single algal clade, 'cryptic zooxanthellae' have not surfaced in any of the long-term studies.

(4) Can early ontogeny provide a window to acquiring new zooxanthella genotypes in those coral species where the adults do not change zooxanthella genotypes? The few studies on zooxanthellae in newly settled polyps of coral species that host only 1 zooxanthella clade as adults suggest that the primary polyp stage is more flexible to hosting multiple zooxanthella genotypes, even from different algal clades (Coffroth et al. 2001). For example, newly settled polyps of the octocoral Pseudoplexaura porosa host either Clade A, B, C or a mixture of A and B algae (Coffroth et al. 2001). Newly settled polyps of Plexaura kuna either host Clade A, Clade B, or a mixture of both algae (Coffroth et al. 2001). On the other hand, all juvenile $P$. porosa and $P$. kuna colonies $(\geq 3 \mathrm{~cm}$ ) sampled in nature host only Clade B (Coffroth et al. 2001). Adult P. porosa and $P$. kuna colonies also only host Clade B zooxanthellae (Goulet \& Coffroth 2003a,b, 2004).

The adult colonies' zooxanthella complement may arise by at least 2 processes: (1) Newly settled polyps that acquire a zooxanthella clade not found in the adults may die. Consequently, only polyps hosting the clade found in the adults will survive to the juvenile and adult stage. (2) Competition among zooxanthellae may occur in newly settled coral polyps. The zoo- xanthellae belonging to the clade characteristic of the adults may outcompete all other zooxanthellae, resulting in all adult colonies hosting only one zooxanthella clade. In Plexaura kuna, all adult colony clonemates host the same specific individual genotype within Clade B, demonstrating a lack of zooxanthella turnover even at the within-clade level (Goulet \& Coffroth $2003 a, b)$. Therefore, from the few studies comparing zooxanthellae in newly settled polyps and adult colonies in coral species where the adults host a single zooxanthella clade, it does not appear that switching of clades or of types within a clade occurs.

\section{Conclusions}

Given the data available today, the majority of coral species host a single zooxanthella clade. Coral species that are in symbiosis with only 1 zooxanthella clade may host several types within a clade, but an individual coral colony does not switch its type over time, when transplanted to different environments or when subjected to stressors such as disease or increased temperatures.

In the context of global climate change, the majority of coral species may not be able to switch symbionts and may be in greater peril than some studies imply. How the remaining $23 \%$ of coral species are capable of hosting multiple zooxanthella clades remains to be determined. For the majority of corals, the question is not whether symbiont change is possible, but under which conditions the existing symbiosis may survive. If global climate change continues, coral reefs may undergo a significant change in biodiversity, as only a small subset of symbiotic stony coral and octocoral species may survive.

Acknowledgements. I thank C. Simmons for generating Fig. 1, and R. Buchholz, C. Cook, W. Fitt, D. Goulet, T. LaJeunesse, H. Lenhoff, C. Ochs, S. Threlkeld and 3 anonymous reviewers for reading earlier versions of this article. This work was funded by NASA grant NAG13-02052, for support of the University of Mississippi Geoinformatics Center.

\section{LITERATURE CITED}

Baker AC (1999) The symbiosis ecology of reef-building corals. PhD dissertation, University of Miami, Miami, FL

Baker AC (2001) Reef corals bleach to survive change. Nature 411:765-766

Baker AC (2003) Flexibility and specificity in coral-algal symbiosis: diversity, ecology, and biogeography of Symbiodinium. Annu Rev Ecol Evol Syst 34:661-689

Baker AC, Rowan R (1997) Diversity of symbiotic dinoflagellates (zooxanthellae) in scleractinian corals of the Caribbean and Eastern Pacific. Proc 8th Int Coral Reef Symp 2:1301-1306 
Baker AC, Rowan R, Knowlton N (1997) Symbiosis ecology of two Caribbean acroporid corals. Proc 8th Int Coral Reef Symp 2:1295-1300

Baker AC, Starger CJ, McClanahan TR, Glynn PW (2004) Coral reefs: corals' adaptive response to climate change. Nature 430:741

Barneah O, Weis VM, Perez S, Benayahu Y (2004) Diversity of dinoflagellate symbionts in Red Sea soft corals: mode of symbiont acquisition matters. Mar Ecol Prog Ser 275: 89-95

Berkelmans R, van Oppen MJH (2006) The role of zooxanthellae in the thermal tolerance of corals: a 'nugget of hope' for coral reefs in an era of climate change. Proc R Soc Lond B (in press) doi:10.1098/rspb.2006.3567

Bhagooli R, Hidaka M (2004) Photoinhibition, bleaching susceptibility and mortality in two scleractinian corals, Platygyra ryukyuensis and Stylophora pistillata, in response to thermal and light stresses. Comp Biochem Physiol A 137:547-555

Billinghurst Z, Douglas AE, Trapido-Rosenthal HG (1997) On the genetic diversity of the symbiosis between the coral Montastraea cavernosa and zooxanthellae in Bermuda. Proc 8th Int Coral Reef Symp 2:1291-1294

Brown BE, Downs CA, Dunne RP, Gibb SW (2002) Exploring the basis of thermotolerance in the reef coral Goniastrea aspera. Mar Ecol Prog Ser 242:119-129

Buddemeier RW, Fautin DG (1993) Coral bleaching as an adaptive mechanism. Bioscience 43:320-326

Chen CA, Yang YW, Wei NV, Tsai WS, Fang LS (2005) Symbiont diversity in scleractinian corals from tropical reefs and subtropical non-reef communities in Taiwan. Coral Reefs 24:11-22

Coffroth MA, Santos SR (2005) Genetic diversity of symbiotic dinoflagellates in the genus Symbiodinium. Protist 156: 19-34

Coffroth MA, Santos SR, Goulet TL (2001) Early ontogenetic expression of specificity in a cnidarian-algal symbiosis. Mar Ecol Prog Ser 222:85-96

Darius HT, Dauga C, Grimont PAD, Chungue E, Martin PMV (1998) Diversity in symbiotic dinoflagellates (Pyrrhophyta) from seven scleractinian coral species: restriction enzyme analysis of small subunit ribosomal RNA genes. J Eukaryot Microbiol 45:619-627

Darius HT, Martin PMV, Grimont PAD, Dauga C (2000) Small subunit rDNA sequence analysis of symbiotic dinoflagellates from seven scleractinian corals in a Tahitian lagoon. J Phycol 36:951-959

Diekmann OE, Bak RPM, Tonk L, Stam WT, Olsen JL (2002) No habitat correlation of zooxanthellae in the coral genus Madracis on a Curaçao reef. Mar Ecol Prog Ser 227: 221-232

Diekmann OE, Olsen JL, Stam WT, Bak RPM (2003) Genetic variation within Symbiodinium clade B from the coral genus Madracis in the Caribbean (Netherlands Antilles). Coral Reefs 22:29-33

Douglas AE (2003) Coral bleaching-how and why? Mar Pollut Bull 46:385-392

Fabricius KE, Mieog JC, Colin PL, Idip D, van Oppen MJH (2004) Identity and diversity of coral endosymbionts (zooxanthellae) from three Palauan reefs with contrasting bleaching, temperature and shading histories. Mol Ecol 13:2445-2458

Fautin DG, Buddemeier RW (2004) Adaptive bleaching: a general phenomenon. Hydrobiologia 530/531:459-467

Glynn PW (1996) Coral reef bleaching: facts, hypotheses and implications. Global Change Biol 2:495-509

Goulet TL, Coffroth MA (1997) A within colony comparison of zooxanthellae genotypes in the Caribbean gorgonian Plexaura kuna. Proc 8th Int Coral Reef Symp 2:1331-1334

Goulet TL, Coffroth MA (2003a) Genetic composition of zooxanthellae between and within colonies of the octocoral Plexaura kuna, based on small subunit rDNA and multilocus DNA fingerprinting. Mar Biol 142:233-239

Goulet TL, Coffroth MA (2003b) Stability of an octocoral-algal symbiosis over time and space. Mar Ecol Prog Ser 250: $117-124$

Goulet TL, Coffroth MA (2004) The genetic identity of dinoflagellate symbionts in Caribbean octocorals. Coral Reefs 23:465-472

Goulet TL, Cook CB, Goulet D (2005) Effects of short-term exposure to elevated temperatures and light levels on photosynthesis of different host-symbiont combinations in the Aiptasia pallida/Symbiodinium symbiosis. Limnol Oceanogr 50:1490-1498

Hoegh-Guldberg O (1999) Climate change, coral bleaching and the future of the world's coral reefs. Mar Freshw Res 50:839-866

Iglesias-Prieto R, Beltran VH, LaJeunesse TC, Reyes-Bonilla $H$, Thome PE (2004) Different algal symbionts explain the vertical distribution of dominant reef corals in the eastern Pacific. Proc R Soc Lond B 271:1757-1763

Karako-Lampert S, Katcoff DJ, Achituv Y, Dubinsky Z, Stambler N (2004) Do clades of symbiotic dinoflagellates in scleractinan corals of the Gulf of Eilat (Red Sea) differ from those of other coral reefs? J Exp Mar Biol Ecol 311:301-314

Kirk NL, Ward JR, Coffroth MA (2005) Stable Symbiodinium composition in the sea fan Gorgonia ventalina during temperature and disease stress. Biol Bull 209:227-234

LaJeunesse TC (2002) Diversity and community structure of symbiotic dinoflagellates from Caribbean coral reefs. Mar Biol 141:387-400

LaJeunesse TC, Loh WKW, van Woesik R, Hoegh-Guldberg O, Schmidt GW, Fitt WK (2003) Low symbiont diversity in southern Great Barrier Reef corals, relative to those of the Caribbean. Limnol Oceanogr 48:2046-2054

LaJeunesse TC, Thornhill DJ, Cox EF, Stanton FG, Fitt WK, Schmidt GW (2004) High diversity and host specificity observed among symbiotic dinoflagellates in reef coral communities from Hawaii. Coral Reefs 23:596

LaJeunesse TC, Lee S, Bush S, Bruno JF (2005) Persistence of non-Caribbean algal symbionts in Indo-Pacific mushroom corals released to Jamaica 35 years ago. Coral Reefs 24: $157-159$

Lewis CL, Coffroth MA (2004) The acquisition of exogenous algal symbionts by an octocoral after bleaching. Science 304:1490-1492

Little AF, van Oppen MJH, Willis BL (2004) Flexibility in algal endosymbioses shapes growth in reef corals. Science 304 : 1492-1494

Loh WKW, Carter D, Hoegh-Guldberg O (1997) Diversity of zooxanthellae from scleractinian corals of One Tree Island (The Great Barrier Reef). In: Greenwood JG, Hall NJ (eds) Proc Aust Coral Reef Soc 75th Anniversary Conf, p 141-150

Loh WKW, Loi T, Carter D, Hoegh-Guldberg O (2001) Genetic variability of the symbiotic dinoflagellates from the wide ranging coral species Seriatopora hystrix and Acropora longicyathus in the Indo-West Pacific. Mar Ecol Prog Ser 222:97-107

Loya Y, Sakai K, Yamazato K, Nakano Y, Sambali H, van Woesik R (2001) Coral bleaching: the winners and the losers. Ecol Lett 4:122-131

McNally KL, Govind NS, Thomé PE, Trench RK (1994) Smallsubunit ribosomal DNA sequence analyses and a recon- 
struction of the inferred phylogeny among symbiotic dinoflagellates (Pyrrophyta). J Phycol 30:316-329

Rodriguez-Lanetty M, Hoegh-Guldberg O (2003) Symbiont diversity within the widespread scleractinian coral Plesiastrea versipora, across the northwestern Pacific. Mar Biol 143:501-509

Rodriguez-Lanetty M, Cha HR, Song JI (2000) Genetic diversity of symbiotic dinoflagellates associated with anthozoans from Korean waters. Proc 9th Int Coral Reef Symp, p 23-27

Rodriguez-Lanetty M, Chang SJ, Song JI (2003) Specificity of two temperate dinoflagellate-anthozoan associations from the northwestern Pacific Ocean. Mar Biol 143: 1193-1199

Rodriguez-Lanetty M, Krupp DA, Weis VM (2004) Distinct ITS types of Symbiodinium in Clade C correlate with cnidarian/dinoflagellate specificity during onset of symbiosis. Mar Ecol Prog Ser 275:97-102

Rowan R (2004) Coral bleaching: thermal adaptation in reef coral symbionts. Nature 430:742

Rowan R, Knowlton N (1995) Intraspecific diversity and ecological zonation in coral-algal symbiosis. Proc Natl Acad Sci USA 92:2850-2853

Rowan R, Powers DA (1991a) A molecular genetic classification of zooxanthellae and the evolution of animal-algal symbiosis. Science 251:1348-1351

Rowan R, Powers DA (1991b) Molecular genetic identification of symbiotic dinoflagellates (zooxanthellae). Mar Ecol Prog Ser 71:65-73

Rowan R, Knowlton N, Baker A, Jara J (1997) Landscape ecology of algal symbionts creates variation in episodes of coral bleaching. Nature 388:265-269

Santos SR, Taylor DJ, Coffroth MA (2001) Genetic comparisons of freshly isolated versus cultured symbiotic dinoflagellates: implications for extrapolating to the intact symbiosis. J Phycol 37:900-912

Santos SR, Gutierrez-Rodriguez C, Coffroth MA (2003a) Phylogenetic identification of symbiotic dinoflagellates via length heteroplasmy in domain $\mathrm{V}$ of chloroplast large subunit (cp23S)-ribosomal DNA sequences. Mar Biotechnol 5:1-11

Santos SR, Gutierrez-Rodriguez C, Coffroth MA (2003b) Symbiodinim sp. associations in the gorgonian Pseudo-

Editorial responsibility: Howard I. Browman (Associate Editor-in-Chief), Storebø, Norway pterogorgia elisabethae in the Bahamas: high levels of genetic variability and population structure in symbiotic dinoflagellates. Mar Biol 143:111-120

Savage AM, Goodson MS, Visram S, Trapido-Rosenthal H, Wiedenmann J, Douglas AE (2002) Molecular diversity of symbiotic algae at the latitudinal margins of their distribution: dinoflagellates of the genus Symbiodinium in corals and sea anemones. Mar Ecol Prog Ser 244:17-26

Stat M, Carter D, Hoegh-Guldberg O (2006) The evolutionary history of Symbiodinium and scleractinian hostssymbiosis, diversity, and the effect of climate change. Perspect Plant Ecol Evol Syst (in press) doi:10.1016/ j.ppees.2006.04.001

Toller WW, Rowan R, Knowlton N (2001a) Repopulation of zooxanthellae in the Caribbean corals Montastraea annularis and $M$. faveolata following experimental and disease-associated bleaching. Biol Bull 201:360-373

Toller WW, Rowan R, Knowlton N (2001b) Zooxanthellae of the Montastraea annularis species complex: patterns of distribution of four taxa of Symbiodinium on different reefs and across depths. Biol Bull 201:348-359

Ulstrup KE, van Oppen MJH (2003) Geographic and habitat partitioning of genetically distinct zooxanthellae (Symbiodinium) in Acropora corals on the Great Barrier Reef. Mol Ecol 12:3477-3484

van Oppen MJH, Palstra FP, Piquet AMT, Miller DJ (2001) Patterns of coral-dinoflagellate associations in Acropora: significance of local availability and physiology of Symbiodinium strains and host-symbiont selectivity. Proc R Soc Lond B 268:1759-1767

Visram S, Douglas AE (2006) Molecular diversity of symbiotic algae (zooxanthellae) in scleractinian corals of Kenya. Coral Reefs 25:172-176

Wilcox TP (1997) The evolution of algal-invertebrate symbioses. $\mathrm{PhD}$ dissertation, University of Houston, Houston, TX

Wilcox TP (1998) Large-subunit ribosomal RNA systematics of symbiotic dinoflagellates: morphology does not recapitulate phylogeny. Mol Phylogen Evol 10:436-448

Yang YA, Soong K, Chen CA (2002) Seasonal variation in symbiont community composition within single colonies of Acropora palifera. Proc 9th Int Coral Reef Symp 1:37

Submitted: June 15, 2006; Accepted: August 2, 2006

Proofs received from author(s): August 23, 2006 